\title{
Comparison the Effectiveness of Mindfulness Training and Massage-Aromatherapy on Rising Psychological Health of Elderly Women with Chronic Pain
}

Sima Alemi

PhD Student of Health Psychology, Department of Psychology, Karaj Branch, faculty of psychology, Islamic Azad University, Karaj, Iran

\section{Saeid Malihialzackerini}

Assistant Professor, Department of Psychology, Karaj Branch, faculty of psychology, Islamic Azad University, Karaj, Iran. (Corresponding Author): Email: saied.malihi@kiau.ac.ir

Khadijeh Abolmaali Alhoseini Associate Professor, Department of Psychology, Roudehan Branch, faculty of psychology, Islamic Azad University, Roudehen, Iran

Mohammad Khabiri

Associate Professor, Department of Sport Management, Faculty of Physical Education \& Sport Sciences, Tehran University, Tehran, Iran

Received: 04 January 2019

Accepted: 19 June 2019

DOI: 10.29252/ijhehp.7.4.359

\begin{abstract}
Background and Objective: One of the most common signs of aging that effects on health is a chronic pain. There are various methods to improve health such as mindfulness and massage-aromatherapy. This study aimed to compare the effectiveness of mindfulness training and massage-aromatherapy on psychological health of elderly women with chronic pain.

Materials and Methods: Present study was a Quasi-experimental with pre-test and post-test design. Research population was elderly women with chronic pain referring to clinics of rehabilitation, orthopedic and physiotherapy of west Tehran in 2017.45 people were selected by available sampling method and randomly assigned into three group. Experimental groups trained 8 sessions of 90 minutes by methods of mindfulness and massage-aromatherapy, respectively and the control group was placed on the waiting list for training. The research instruments were the questionnaires of perceived stress, geriatric depression, quality of life and perception of pain. Data were analyzed by multivariate analysis of covariance and Bonferroni post hoc test methods.
\end{abstract}

Results: The findings showed that both methods of mindfulness training and massagearomatherapy led to significant decrease the perceived stress and depression of elderly women with chronic pain, but didn't have a significant effect on their quality of life and perception of pain. Also, there was no significant difference between two methods of mindfulness training and massage-aromatherapy $(P<0 / 05)$.

Conclusion: The results indicated the effectiveness of mindfulness training and massage-aromatherapy on perceived stress and depression of elderly women with chronic pain. Therefore, these methods can be used along with other methods to improve some characteristics associated with psychological health.

Keywords: Mindfulness, Massage-Aromatherapy, Psychological health, Elderly women, Chronic pain.

Paper Type: Research Article.

Citation (Vancouver): Alemi S, Malihialzackerini S, Abolmaali Alhoseini Kh, Khabiri M. Comparison the Effectiveness of Mindfulness Training and MassageAromatherapy on Rising Psychological Health of Elderly Women with Chronic Pain. Iran J Health Educ Health Promot. Winter 2020;7(4): 359-370. [Persian]

- Citation (APA): Alemi S., Malihialzackerini S., Abolmaali Alhoseini Kh., Khabiri M. (Winter 2020). Comparison the Effectiveness of Mindfulness Training and MassageAromatherapy on Rising Psychological Health of Elderly Women with Chronic Pain. Iranian Journal of Health Education \& Health Promotion., 7(4),359-370. [Persian] 


\section{مقايسهُ اثربخشى آموزش ذهن آكاهى و ماساز ـ آروماترابِى بر ارتقاء سلامت روانشناختى \\ زنان سالمند مبتلا به درد مزمن}

\section{جكيده}

زمينه و هدف: يكى از شايعترين علائم دوران سالمندى كه بر سلامت تأثير مى گذاردارد، درد مزمن است است.

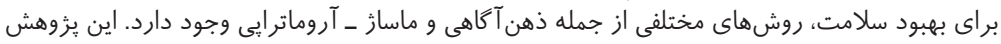

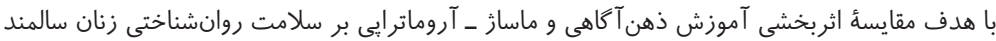

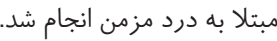

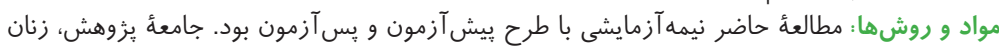

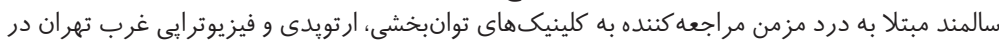

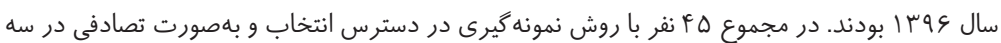

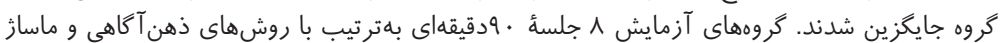

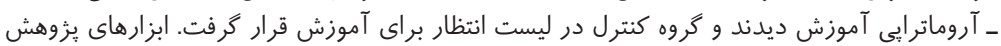

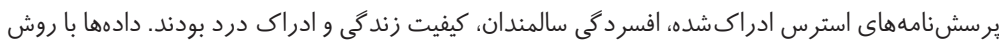

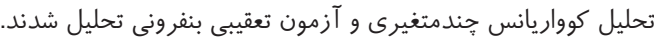

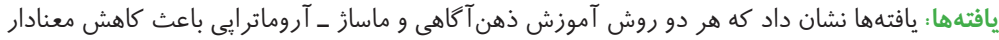

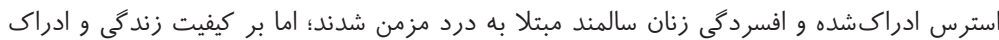

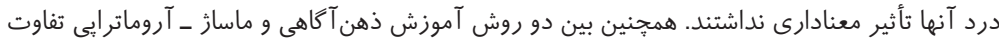

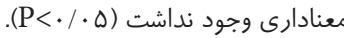

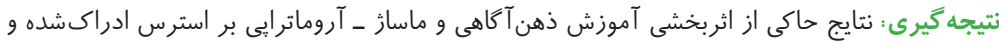

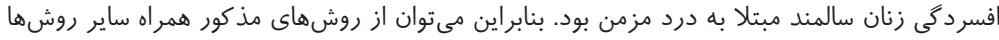

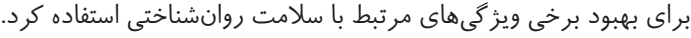

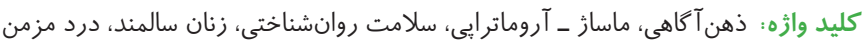

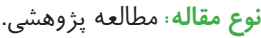

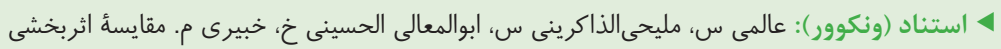

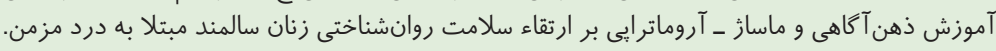

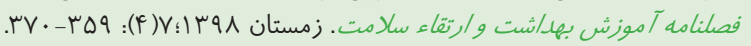

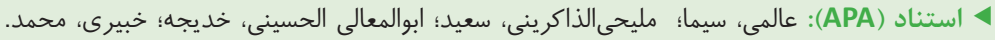

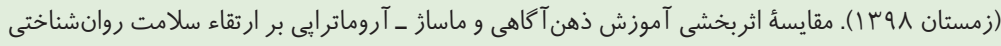

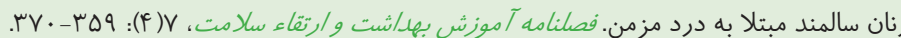

دانشجوى دكترى روانشناسى سلامت، ركروه

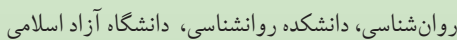
واحد كرج، كرج، ايران

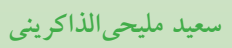

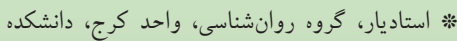

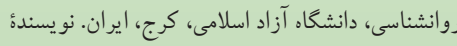
saied.malihi@kiau.ac.ir مسئول: - موانيناسي

$$
\text { خديجه ابو المعالى الحسينى }
$$

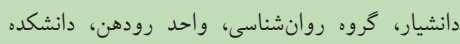

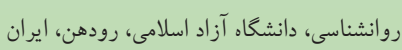
محمد خبيرى دانشيار، كروه مدير يت تريت تربيتبدنى، دانشكدة تربيتبدنى و علوم ورزشى، دانشعاه تهران، تهران، ايران

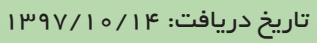

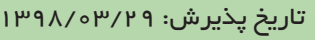




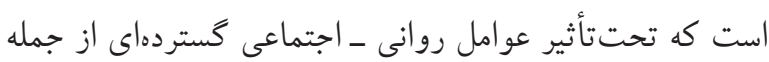
تفاوت هاى فردى، متغيرهاى روانى، فرهنكى، اجتماعى و محيطى قرار مى گيرد ( • (1).

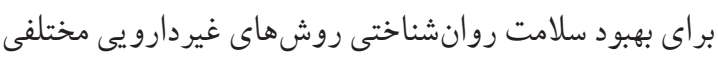

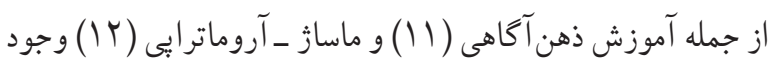

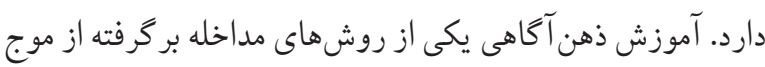

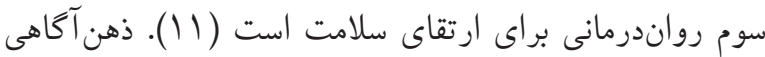

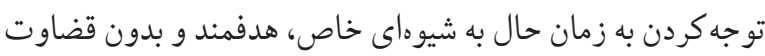

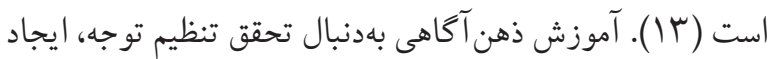

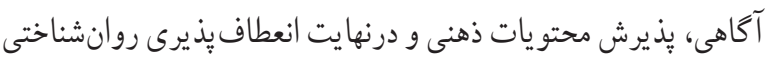

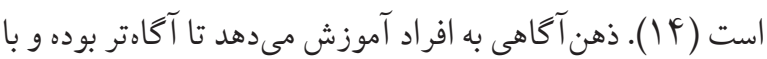

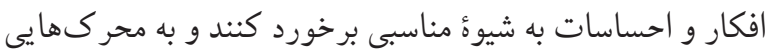

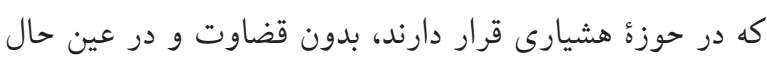

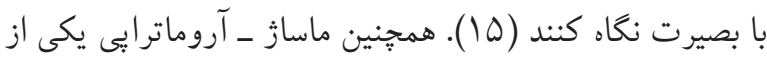
روشهاى طب مكمل براى كاهش مشكلات و ارتقاى سلامت است

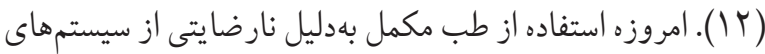
مر اقبتى موجود و اثربخشى طب مكمل افزايش زيادى داشته است

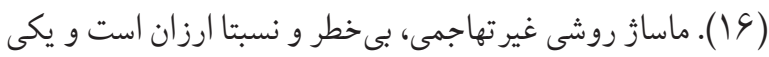
از عمومىترين و برطرفدارترين درمانهاى طب مكمل محسوب مىشود (IV). ماساز انجام يك سرى حر كات منظم روى بافتهاى بدن است كه با فشار ريتميك براى تحقق اهدافى مشخص مثل مان

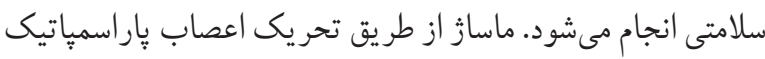
باعث كاهش ضربان قلب، تنفس و اضطراب و افزايش احساس

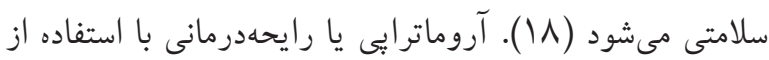

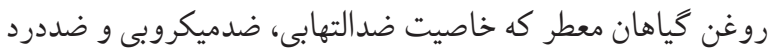

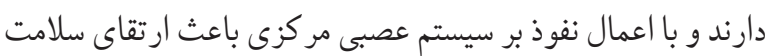

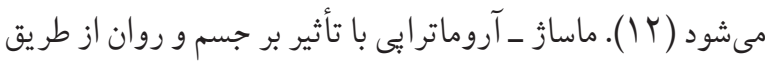

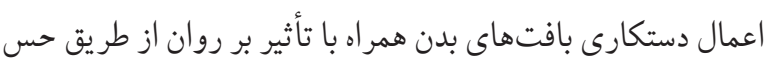
بو يايى باعث افزايش آرامش و سلامت مىشود (19)

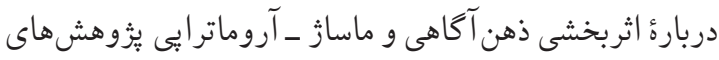

G.. آمار سالمندان بهسرعت در حال افزايش است و در حال حاضر ميليون نفر با سن بالاى •9 سال وجود دارند كه اين تعداد تا سال

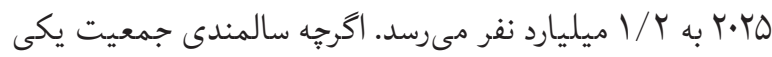
از موفقيتهاى جامعهُ بشرى است؛ اما سالمندى با افزايش روزافزون مشكلات جسمى و روانى همراه است ( (). يكى از شايع ترين مشكلات سالمندان درد مزمن است؛ بهطورى كه حدود يكسوم سالمندان از

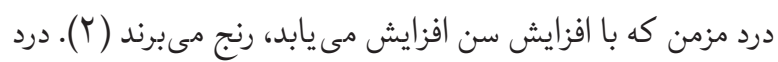

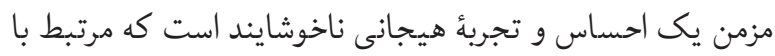

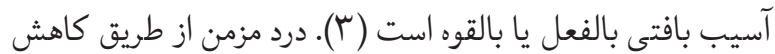

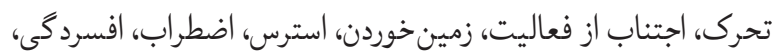

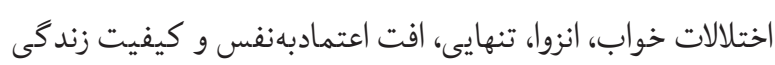
باعث ناتوانى فرد در زندگى مى شود (Y).

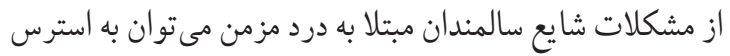

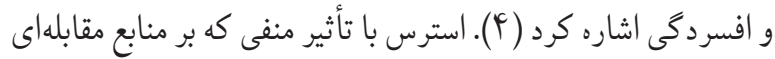
فردى و اجتماعى باعث كاهش سلامت و مقاومت فرد مى شود (ه).

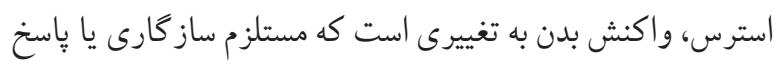

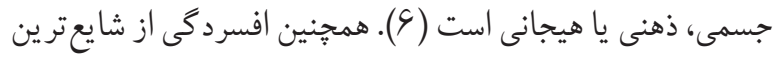

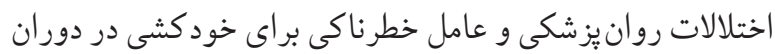

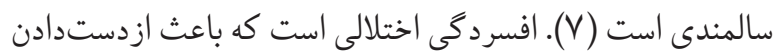

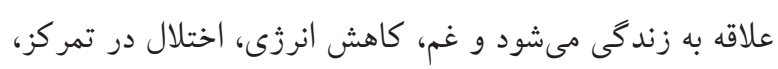

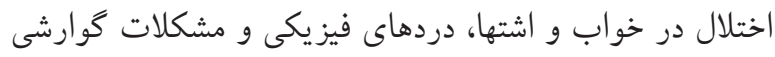
علائم شايع آن هستند (ه).

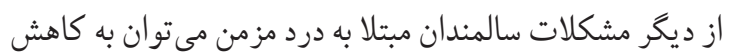

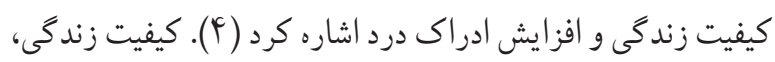
ادراك فرد از موقعيت زندگى براساس اهداف، انتظارات و معيارها با توجه به زمينهاى فرهنكى و نظامهاى ارزشى است (^). كيفيت

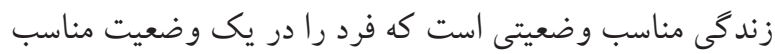

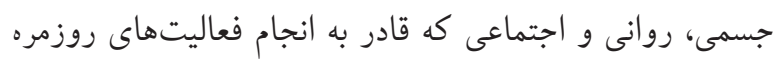

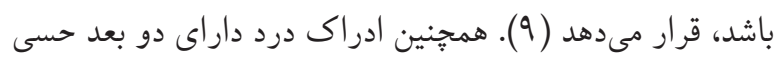

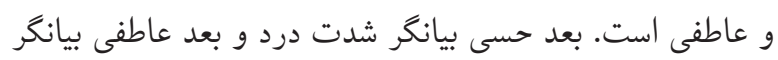


آن از جمله كاهش درد بدنى شد (TV) BVhardoost و همكاران ضمن يزووهشى به اين نتيجه رسيدند كه روش درمانى ماساز شكم

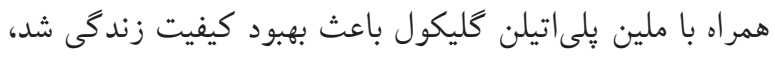

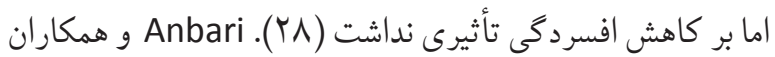

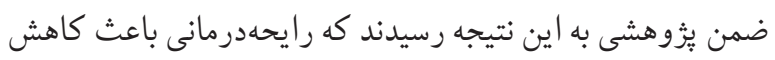

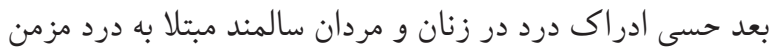

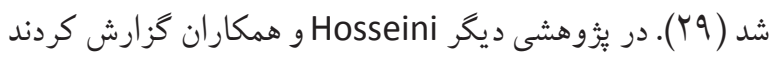

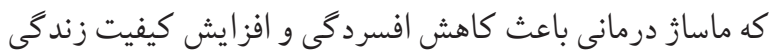

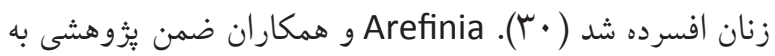

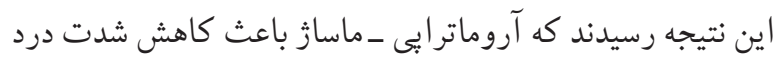

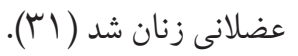

از يكسو آمار سالمندان بهسرعت در حال افزايش است كه اين مسئله با شيوع بالاى مشكلات جسمى و روانى همر اه است ( (1) و از سوى ديخر دردهاى مزمن عمومى ترين علت فشار روانى در دوران

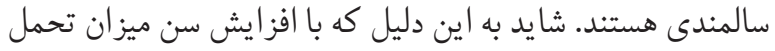

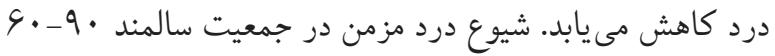
سال حدود VYودرصد گز ارش شده است. آمارها حاكى از آن هستند كه درد مزمن علاوه بر سن با متغير جنسيت نيز ارتباط دارند و درد

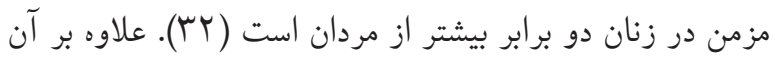

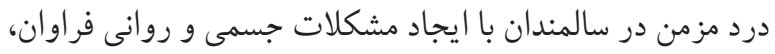
معمولا باعث ناتوانى سالمندان مىشود (Y)؛ بنابر اين بايد بهدنبال

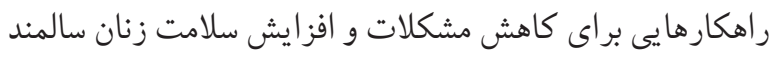
بود. همجنين درمانهاى غيردارويى بهدليل استفادهنكردن از دارو معمولا ارزانتر، غيرتهاجمى و فاقد عوارض دارويى هستند. از

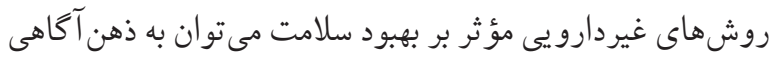

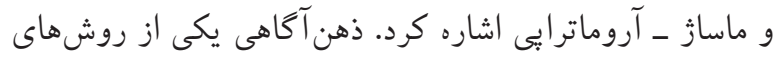

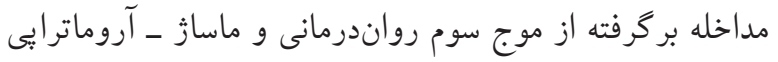
يكى از رايجترين روشهاى طب مكمل است. نكتئ حائز اهميت

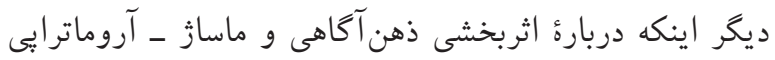

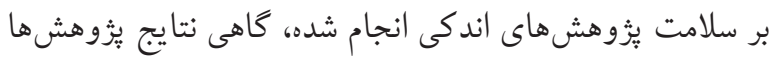
متناقض بوده و يُزوهشى به مقايسة اثربخشى اين دو شيوه نِيرداخته
اندك و گاه متناقض انجام شده است. براى مثال نتايج يزوهش

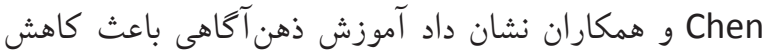

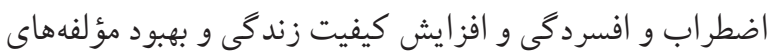

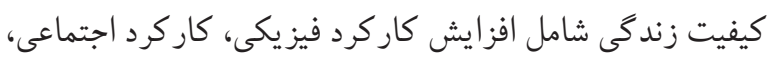
نقش فيزيكى، نقش هيجانى، سلامت عمومى و سرزندگى و كاهش

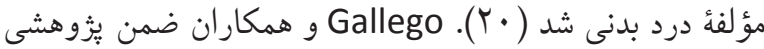

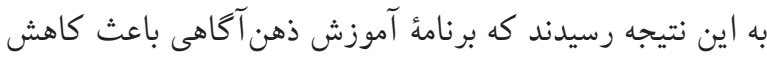

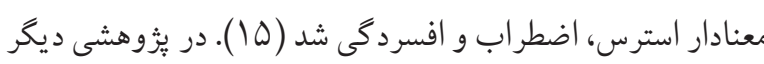
Gok Metin آروماترايى باعث كاهش معنادار درد عصبى و افزايش كيفيت

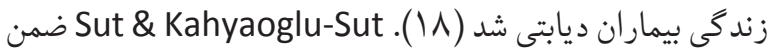

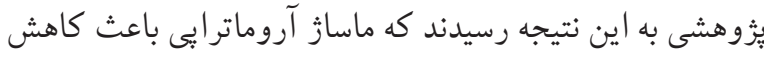

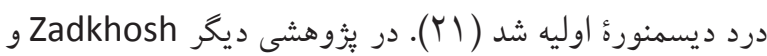

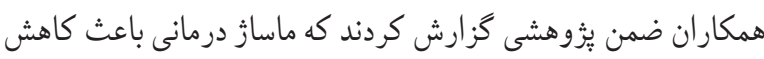

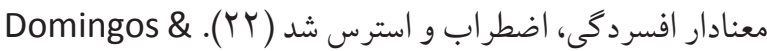
Braga

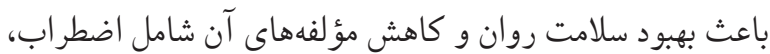
افسردگى، جسمانى سازى و اختلال در عملكرد اجتماعى شد (Y) (I ). همجنين نتايج بُزوهش Pourmohseni Koluri و اسلامى نشان داد كه ذهن آكاهى باعث بهبود كيفيت زندگى و و سلامت روان و و

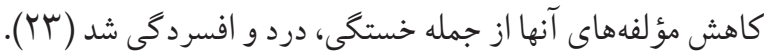
Kharatzadeh و همكاران ضمن بثزوهشى به اين نتيجه رسيدند كه آموزش ذهن آكاهى باعث كاهش استرس بيماران ديابتى شد؛

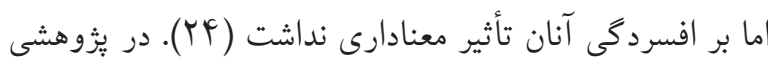

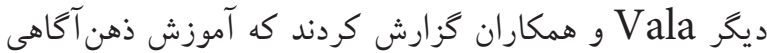

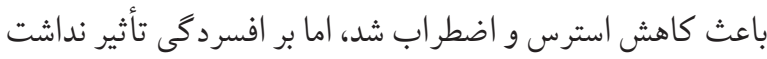
Haddadi Kuhsar.(Yo) رسيدند كه آموزش رويكرد ذهن آكاهى مبتنى بر كاهش استرس باعث كاهش معنادار استرس، اضطر اب و افسردگى در بيماران

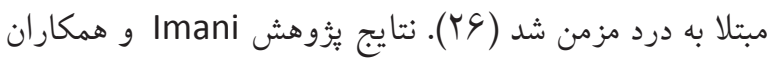

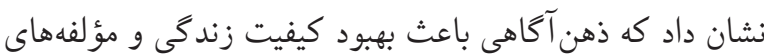


اول، ^ جلسةُ • و دقيقهاى با روش ذهن آكاهى و گروه آزمايش دوم ^جلسةُ • 9 دقيقهاى با روش ماساز ـ آروماتر ابيى (كه بهدليل

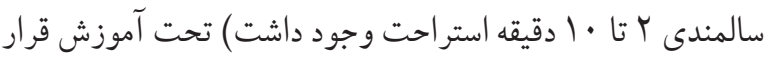

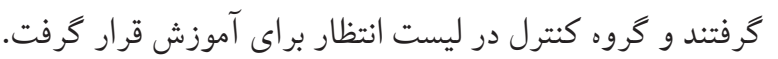

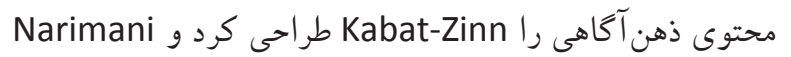

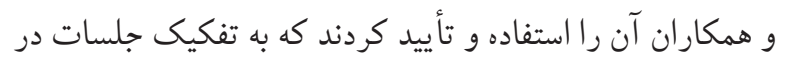

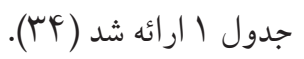

جدول ا. محتوى آموزش ذهن آكاهى به تفكيى جلسات

\begin{tabular}{|c|c|}
\hline محتوى & جلسات \\
\hline 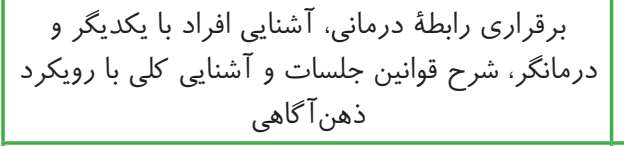 & اول \\
\hline 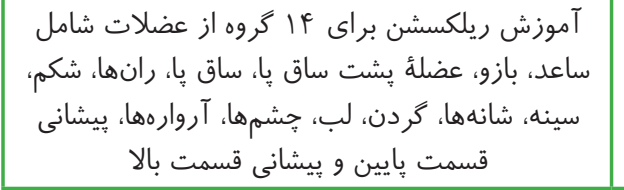 & دوم \\
\hline 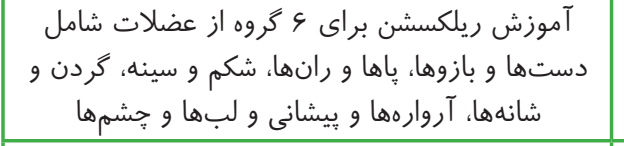 & سوم \\
\hline | & جهارم \\
\hline 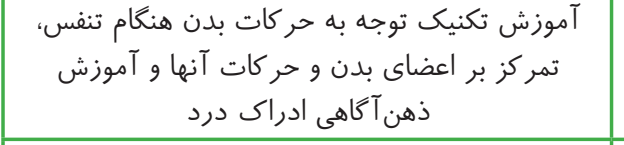 & "ِنجم \\
\hline 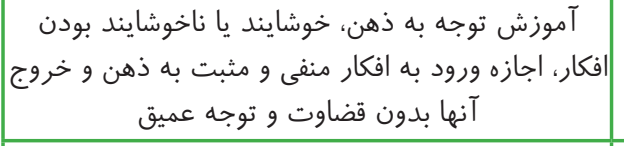 & ششم \\
\hline 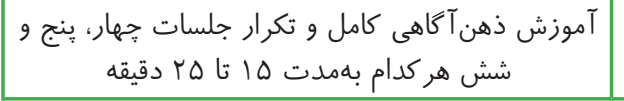 & هفتم \\
\hline مرور و جمعبندى جلسات قبل و ارزيابى نتايج جلسات & هشتم \\
\hline
\end{tabular}

همجنين ماساز ـ آروماترابى طبق برو تكل كلينيك نو آوران

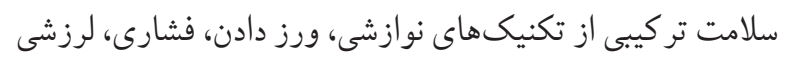

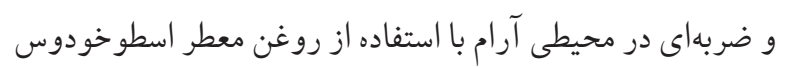

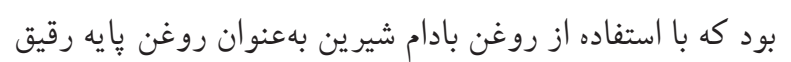
شده بود. ماساز از ناحية يشت تنه و اندام فوقانى شروع، سيس ماساز

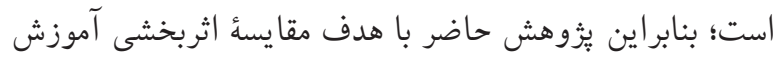

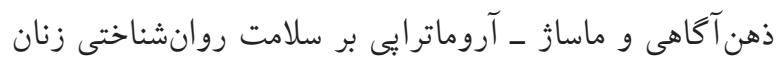
سالمند مبتلا به درد مزمن انجام شد. مو اد و روشها ماهدا

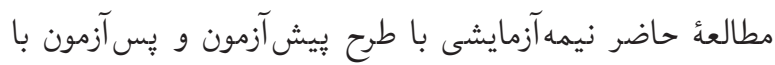

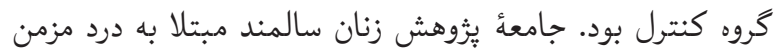

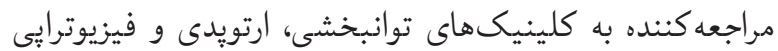

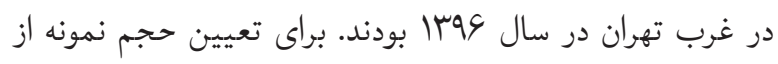
فرمول زير استفاده شد.

$\mathbf{n}=\frac{2 \sigma^{2}\left(z_{1-\frac{\alpha}{2}+} z_{1-\beta}\right)^{2}}{d^{2}}=\frac{2\left(\frac{1}{64}\right)^{2}\left(\frac{1}{96}+\frac{1}{28}\right)^{2}}{\frac{4}{50}}=\frac{\frac{5}{3792} * \frac{10}{4976}}{\frac{4}{507}}=\frac{12}{53}$

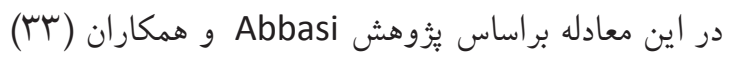

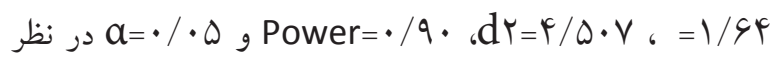

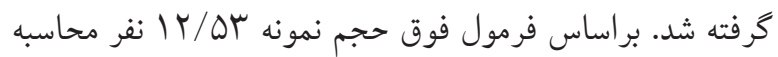

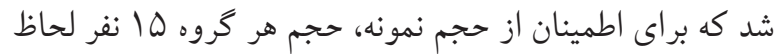

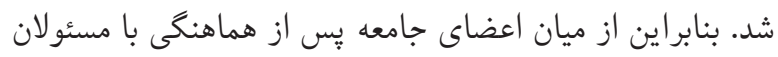

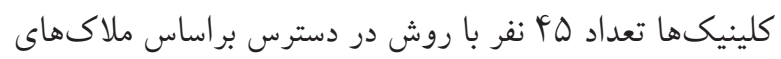

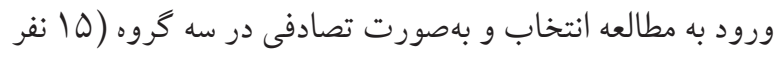

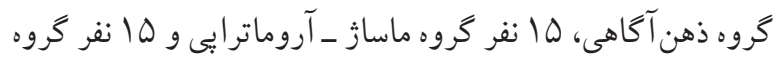

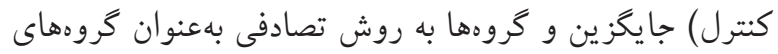
آزمايش يا كنترل انتخاب شدند. ملاكهاى ورود به مطالعه شامل

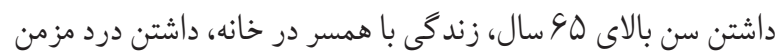
با تشخيص يزشك، داشتن سواد خواندن و نوشتن و استفادنكردن از ساير روشهاى درمانى بهطور همزمان و ملاكهاى خروج شامل

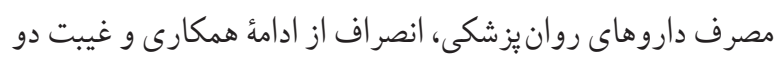

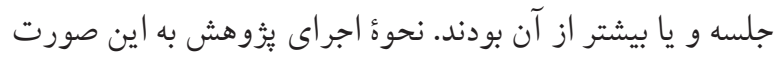

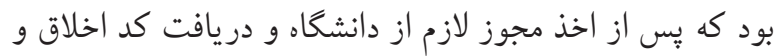

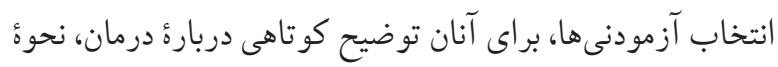

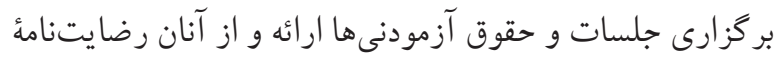

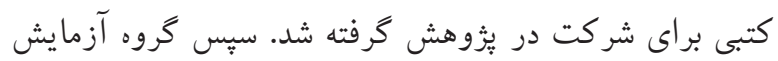




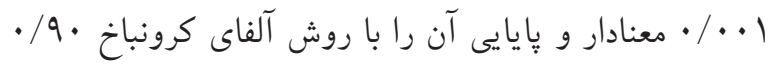

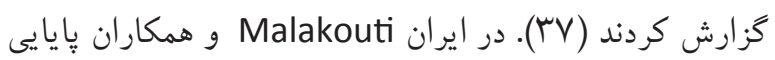

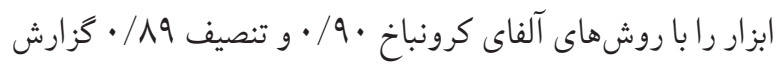

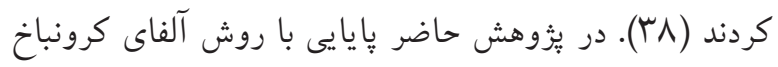

$$
\text { / AV }
$$

براى اندازهگيرى كيفيت زندگى از يرسشنامة Organization

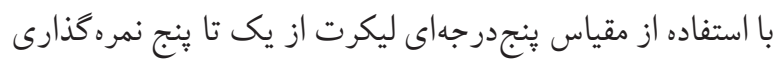

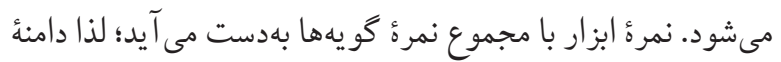

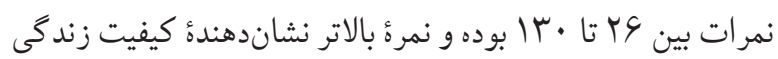
مطلوبتر است. World Health Organization روايى سازه ابزار را تأييد و يايايى آن را با روش آلفاى كرونباخ در كشورهاى

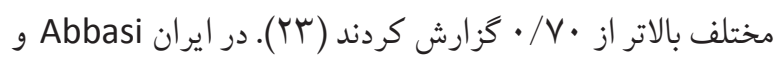

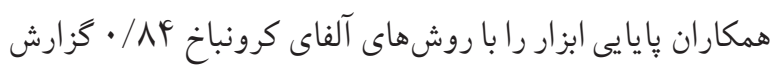

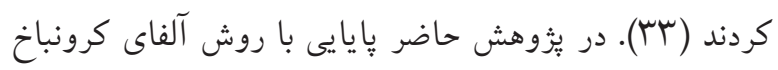

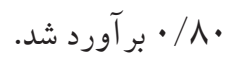

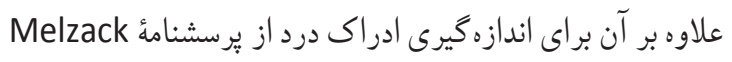

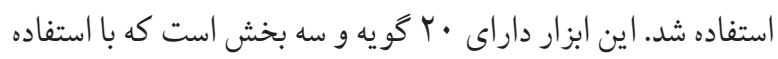

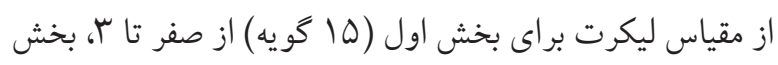

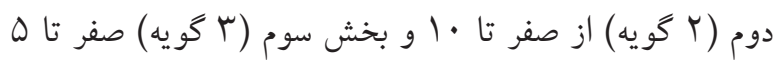

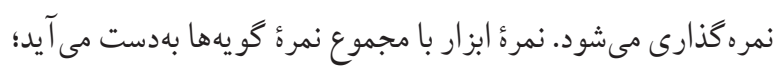

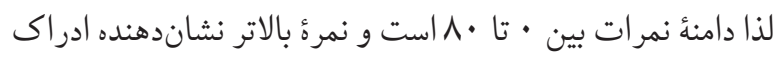

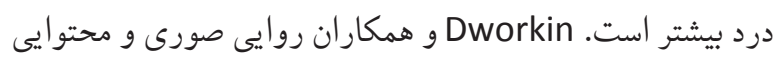

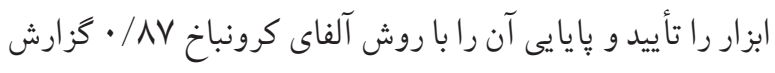

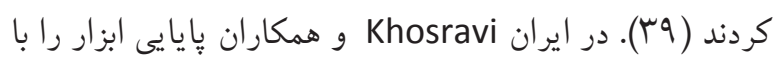

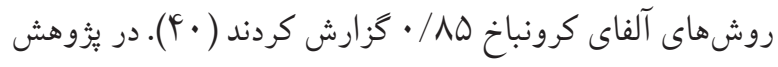

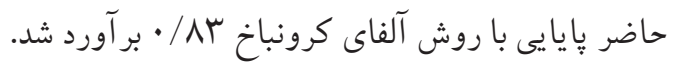

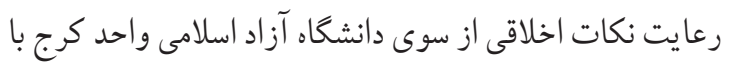

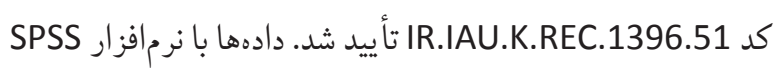
نسخة 19 در سطح ه • / P-value> با روش تحليل كووار يانس جندمتغيرى و آزمون تعقيبى بنفرونى تحليل شدند.

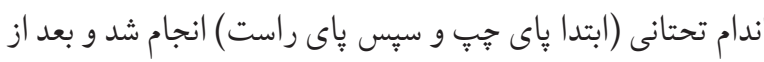

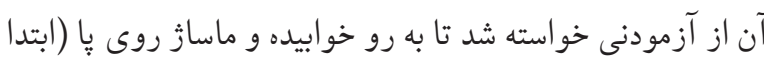

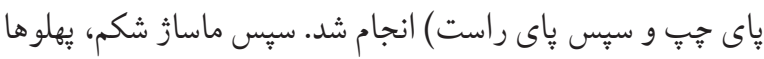

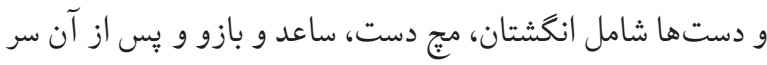

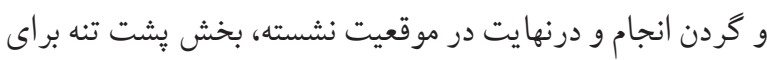
باز گشت بدن به حالت اوليه صورت گرفت. همجنين فر ايند مداخله

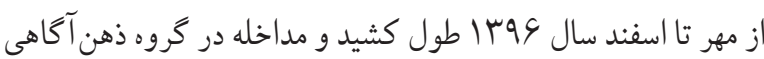
از سوى يك متخصص روانشناسى سلامت و يك فارغالتحصيل

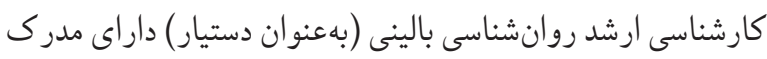

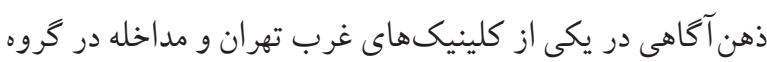

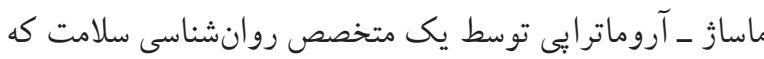

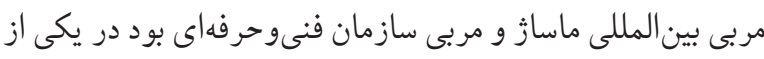

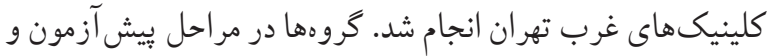
يس آزمون از نظر استرس ادراكشده، افسردگى سالمندان، كيفيت زندگى و ادراك درد با ابزارهاى زير ارزيابى شدند.

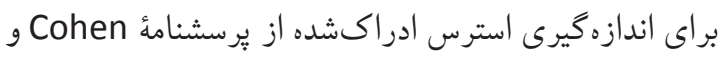

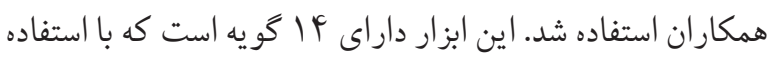
از مقياس ينجدرجهاى ليكرت از صفر تا جهار نمرهذارى مى شود.

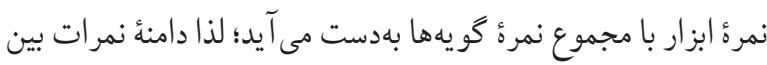

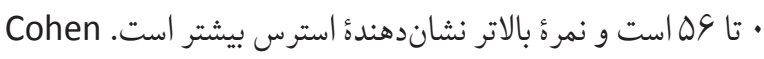

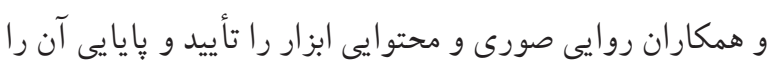

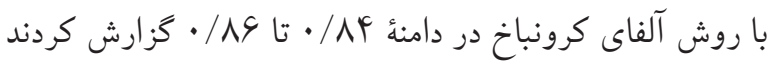
(ه广). در ايران Mousavi و DashtBozorgi

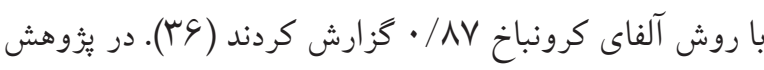

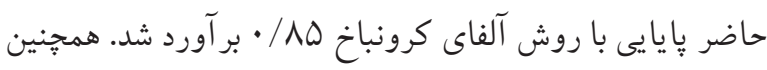

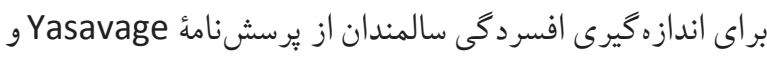

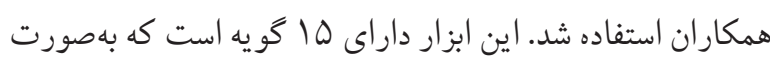

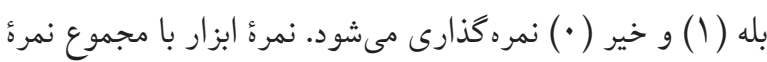

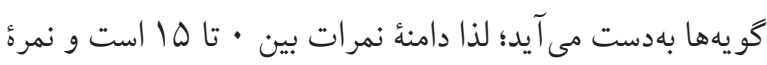
بالاتر نشاندهنده افسردكى بيشتر است. Yasavage و همكاران

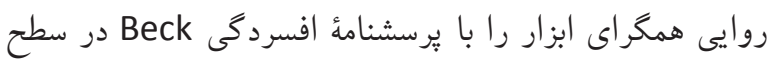


روش تحليل كوواريانس جندمتغيرى برقرار است. جون آزمون

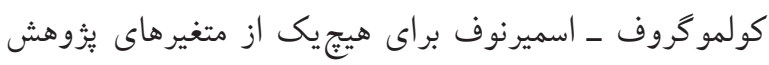

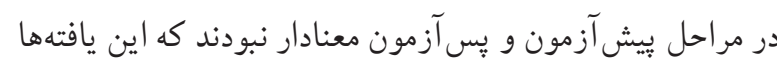

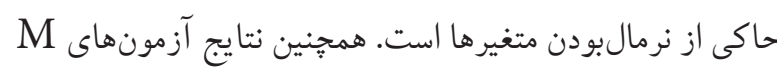

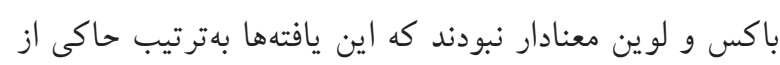
برابرى ماتر يسهاى كوواريانس و برابرى وار يانس ها هستند. علاوه بر آن آزمون كرويت بارتلت معنادار بود كه اين يافته حاكى از براز

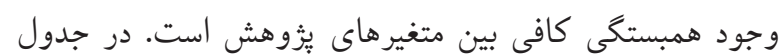

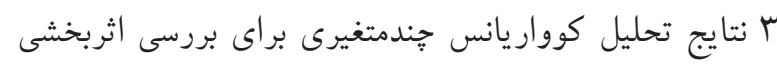

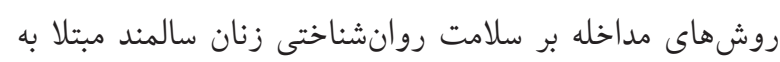

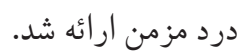

جدول بّ. نتايج آزمون تحليل كوواريانس حندمتغيرى براى بررسى اثربخشى روشهاى مداخله بر سلامت روانشناختى زنان سالمند

مبتلا به درد مزمن مدامب روان

\begin{tabular}{|c|c|c|c|c|c|}
\hline مجذور اتا & P-value & آماره F & مقدار & نوع آزمون & متغير مستقل \\
\hline .1119 & $\cdot / \cdot r \wedge$ & l/Ars & $\cdot / \Delta S V$ & اثر پيلايى & روش هاى مداخله \\
\hline
\end{tabular}

نتايج حاكى از آن است كه روشهاى مداخلة ذهن آكاهى و

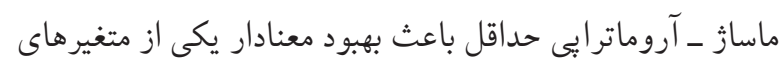

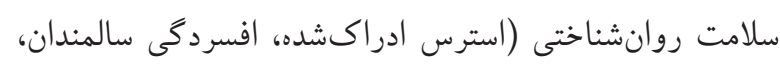

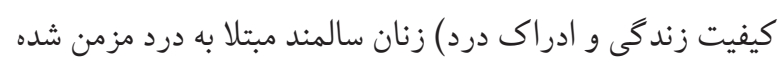

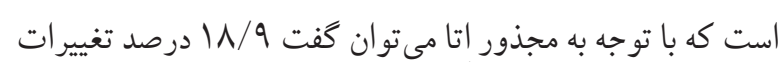

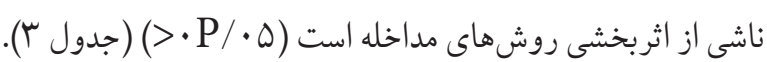

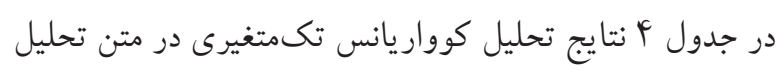

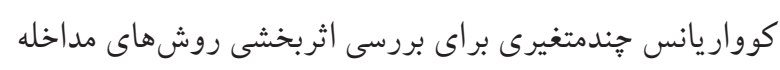

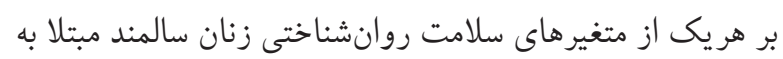

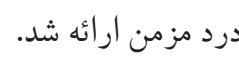
نتايج حاكى از آن است كه روشهاى مداخله باعث كاهش

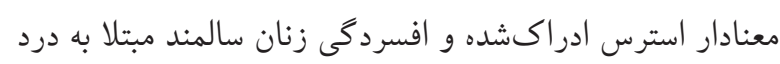

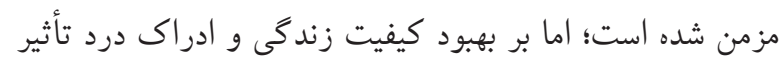

يافتنه

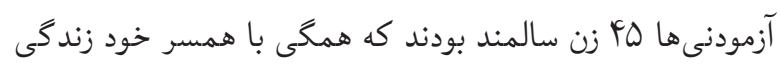

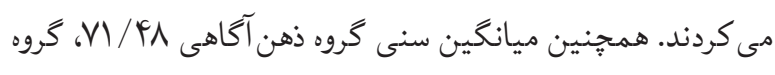

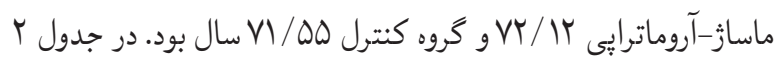

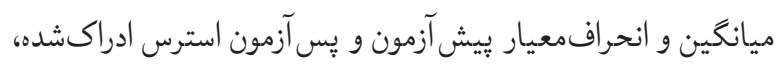

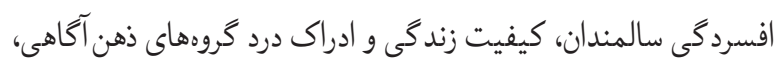
ماساز ـ آروماترايى و كنترل ارائه شد. جدول r. ميانغَين و انحرافمعيار يِيش آزمون و پِّ آزمون

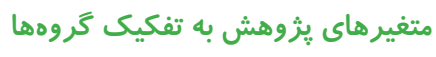

\begin{tabular}{|c|c|c|c|c|c|}
\hline \multicolumn{2}{|c|}{ يس آزمون } & \multicolumn{2}{|c|}{ بيش آزمون } & \multirow{2}{*}{ متغيرها } & \multirow{2}{*}{ كروهها } \\
\hline انحرافمعيار & ميانگين & انحراف معيار & ميانگين & & \\
\hline$r / 91$ & $r q / \cdots$ & $r / V D$ & ऍN/૬V & ادراكشده استر & \multirow{4}{*}{ ذهن آكاهى } \\
\hline $1 / 19$ & ( & $1 / 99$ & $\Lambda / V \mu$ & سالمندان & \\
\hline$\Lambda / \Delta \Delta$ & $\mathrm{Vq} / \mathrm{Ir}$ & N/9V & $S V / \Lambda$. & كيفيت زندكى & \\
\hline$\Delta / \lambda r$ & $F \Delta / q \pi$ & $V / r q$ & $\Delta H / s V$ & ادراى درد & \\
\hline$r / 19$ & $r v / 9 r$ & $r / v$. & $r q / \cdot v$ & ادراكشده استرس & \multirow{4}{*}{ كر وه ماساخ } \\
\hline $1 / 10$ & $V / S V$ & $r /$ rG & $9 / 1$. & سالمندان افسى & \\
\hline$V / 9 F$ & $V q / S V$ & $\wedge / \wedge \Lambda$ & $V \cdot / r V$ & كيفيت زندگى & \\
\hline$\Delta / V T$ & $f \mid / s$. & $s / 01$ & $\Delta r / I r$ & ادراك درد & \\
\hline$p / 91$ & $\mu q / \wedge \Delta$ & $r / \Lambda r$ & $F \mid / F$. & ادراكشده استر & \multirow{4}{*}{ كروه كنترل } \\
\hline$r / F G$ & $q / \cdot V$ & $r / r q$ & N/SV & سالمندان افسى & \\
\hline אוץ & VY/A. & $\Lambda / \Upsilon \Delta$ & VI/VT & كيفيت زندكى & \\
\hline$\Lambda / r \Delta$ & $\Delta F / r V$ & N/IV & $\Delta 1 / V \mu$ & ادراك درد & \\
\hline
\end{tabular}

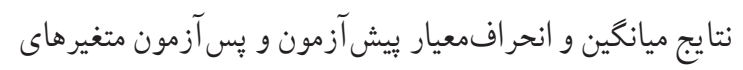

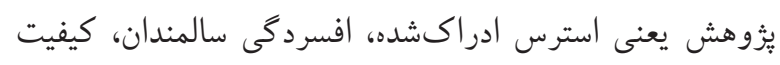

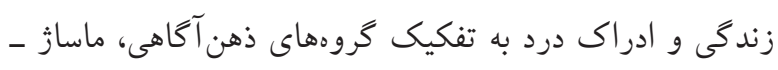

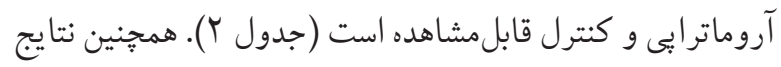
بررسى ييشفرضهاى ثُوهش نشان داد كه شرايط استفاده از 
جدول عا. نتايج تحليل كوواريانس تكمتغيرى در متن تحليل كوواريانس تجندمتغيرى براى بررسى اثربخشى روشهاى مدان مداخله بر هريك از

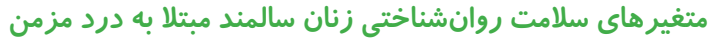

\begin{tabular}{|c|c|c|c|c|c|c|c|}
\hline مجذور إتا & P-Value & آماره F F & ميانگين مجذورات & درجة آزادى & مجموع مجذورات & منبع اثر & متغير ها \\
\hline \multirow[t]{2}{*}{. rutr } &.$/ \mu r$ & S/Ars & $\Lambda ৭ / \% \Delta \Delta$ & r & $|V A / V|$ & 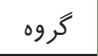 & استرس ادراك شده \\
\hline & & & $|r / \cdot v|$ & ґ & $498 / 991$ & خطا & \\
\hline \multirow[t]{2}{*}{$\cdot|r \mu|$} &.$/ .4$ & r/Vr. & r $1 / 099$ & r & $k r / 19 r$ & كروه اه & افسر دگى \\
\hline & & & $r / \Delta V \Delta$ & ґи & $\mid V r / A \Delta$. & خطا & \\
\hline \multirow[t]{2}{*}{.$/ \cdot r q$} &.$/ 910$ &.$/ 491$ & $r T / 110$ & $r$ & $\kappa \mu / r \mu$. & كرو & كيفيت زندگى \\
\hline & & & $F F / F \cdot V$ & rᄉ & $\mid S \wedge V / 4 \subseteq G$ & خطا & \\
\hline \multirow[t]{2}{*}{.$/ .01$} & $\cdot / F \& V$ & $\cdot / 9 \cdot 1$ & س & r & rVT/OYS & 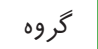 & ادراك درد \\
\hline & & & $101 /$ Tro & ru & $\Delta V F G / 9 \Psi$. & خطا & \\
\hline
\end{tabular}

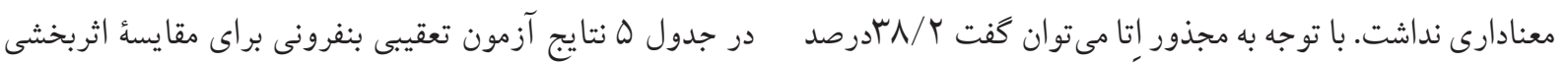

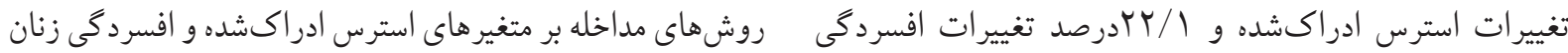

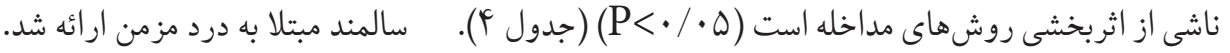
جدول ه. نتايج آزمون تعقيبى بنفرونى براى مقايسة اثربخشى روشهاى مداخله بر متغير هاى استرس ادراكشده و افسردگى زنان سالمند مبتلا به درد مزمن

\begin{tabular}{|c|c|c|c|c|c|}
\hline P-value & خطاى استاندارد & تفاوت ميانكينها & كروه دوم & كروه اول & متغير ها \\
\hline $1 / \cdots$ & $1 / .90$ & . /Grr & ماسار--آروماترايى & ذهن آكاهى & استرس ادراكشده \\
\hline.$/ .4$ & $r / 1.9$ & $-1 r / 9 V$. & كنترل & ذهن آكاهى & \\
\hline$\cdot / \cdot v$ & $r / \cdot \mu \mu$ & $-\mid r / \Lambda G F$ & كنترل & ماسار -آروماتر إبى & \\
\hline.$/ 4 \mu q$ & $1 / \Delta \Delta$. & $-r / T / D$ & ماساز-آروماترايى & ذهن آكاهى & افسردگى سالمندان \\
\hline$\cdot / \cdot r f$ & r/qFA & -r/DFs & كنترل & ذهن آكاهى & \\
\hline . / & $r / 9 \wedge r$ & $r / 9 V I$ & كنترل & ماسار -آروماتر إبى & \\
\hline
\end{tabular}

جندبرابر مى كند؛ لذا بايد بهدنبال راهكارهايى براى كاهش مشكلات

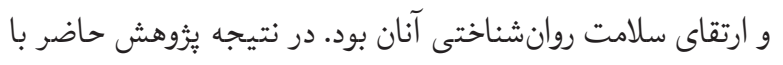
هدف مقايسة اثربخشى آموزش ذهن آكاهى و ماساز ــ آروماترايى إنى بر سلامت روانشناختى زنان سالمند مبتلا به درد مزمن انجام شد.

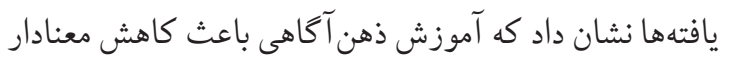

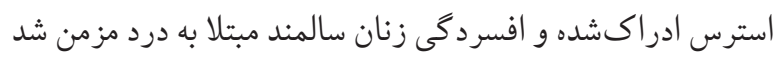
كه اين يافته با يافتهُ يُزوهشهاى Gallego و همكاران (10) (1)،

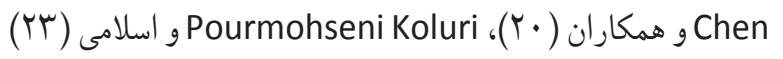
و و و همكاران (Y) (Y) همسو بود. همجنين آموزش

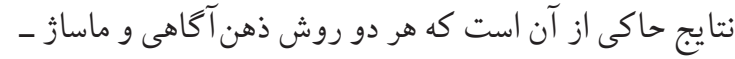

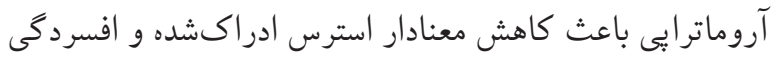

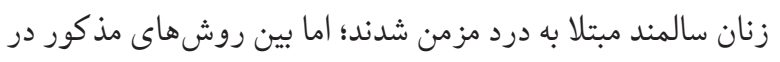
كاهش استرس ادراكشده و افسردگى زنان سالمند مبتلا به درد

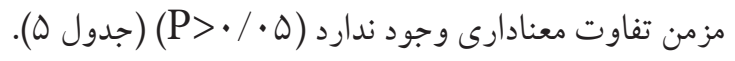
بحث زنان سالمند مبتلا به درد مزمن از يكسو با مشكلات فراوان سالمندى

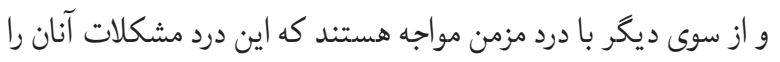


ناهمسو بود. همجنين ماساز ـ آروماترابى تأثير معنادارى بر (YN) افزايش كيفيت زندگى و كاهش ادراك درد آنان نداشت كه اين

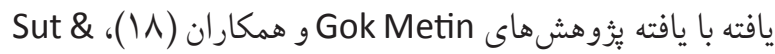
Anbari، BAhardoost،(Y) Kahyaoglu-Sut

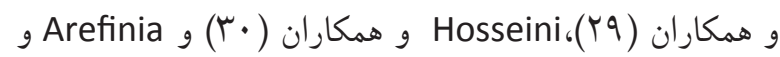

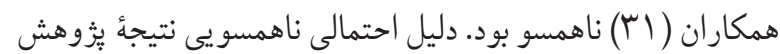

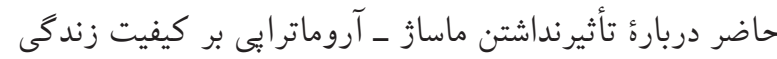

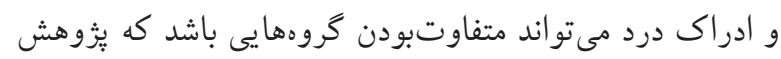

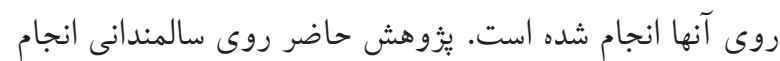

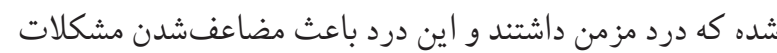

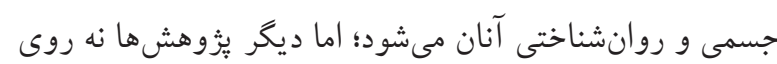

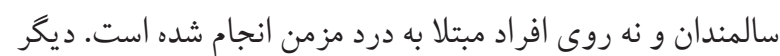

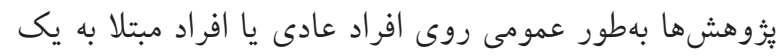

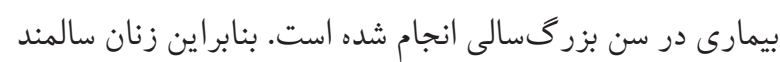

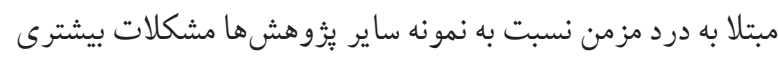
دارند و وقتى مداخله مىتواند مؤثر واقع شود كه تعداد جلسات

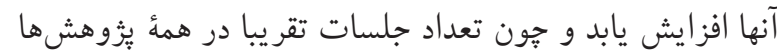

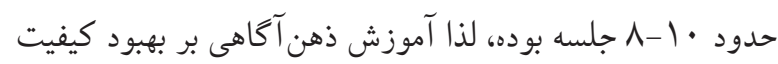

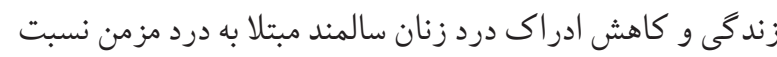
به ساير گروهها مؤثر واقع نشد. همجنين در تبيين اثربخشى ماساز

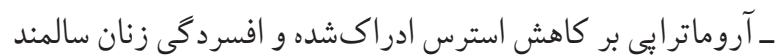

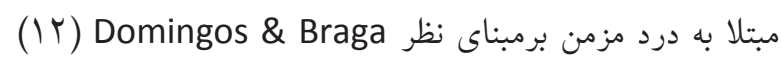

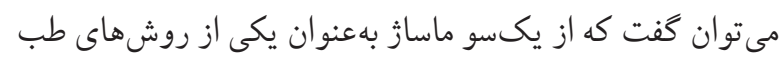

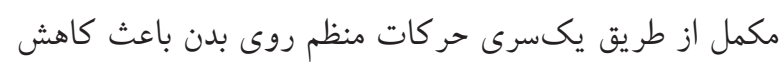

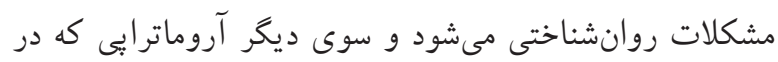

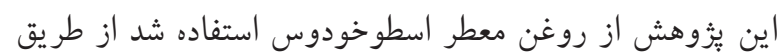

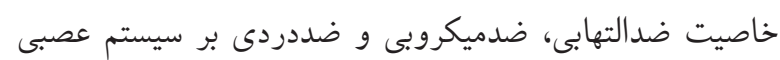
مر كز نفوذ مى كند و باعث كاهش مشكلات روانشناختى مي شود.

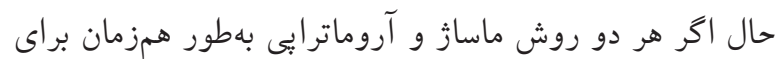

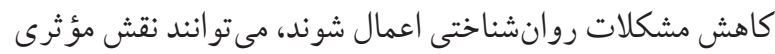
در كاهش مشكلات روانشناختى از جمله استرس و افسردگى داشته
ذهن آكاهى تأثير معنادارى بر افزايش كيفيت زندگى و كاهش

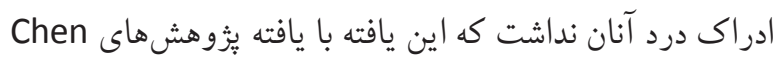

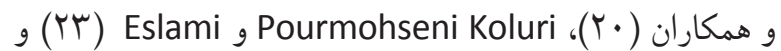
و همكاران (TVani نتيجهُ يُزوهش حاضر دربارهُ تأثيرنداشتن ذهن آكاهى بر كيفيت

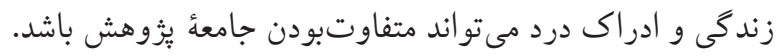
جون جامعهُ اين يُوهش زنان سالمند مبتلا به درد مزمن و جامعه ثِزوهشهاى ديخر افراد فاقد درد مزمن بودند. زنان سالمند مبتلا به درد مزمن براى كاهش ادراك درد و افزايش كيفيت زندگى دئى برخلاف افر اد فاقد درد مزمن نياز به مداخلات با جلسات بيشترى درى دردي

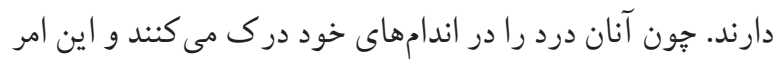

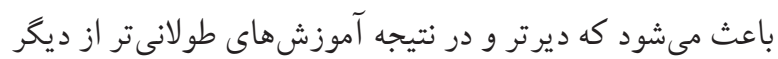

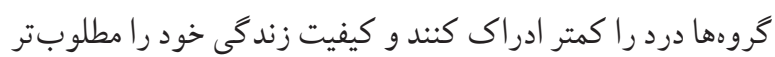
كزارش كنند. همجنين در تبيين اثربخشى ذهن آحاهى بر كاهش

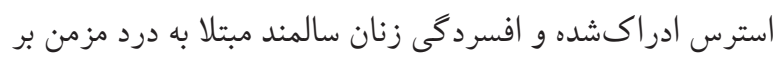

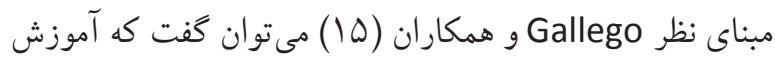
ذهن آكاهى از طريق مشاهده بدون قضاوت افكار، احساسات و

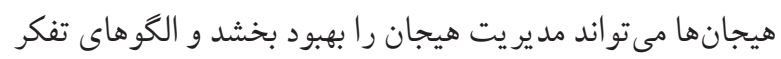

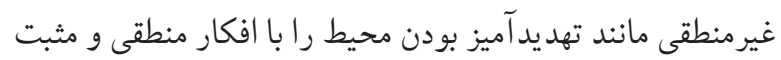
جايگزين كرده و باعث كاهش هيجانهاى منفى شود. همجنين

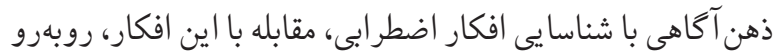

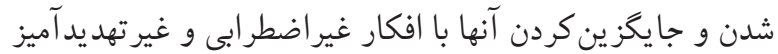

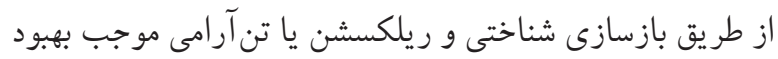

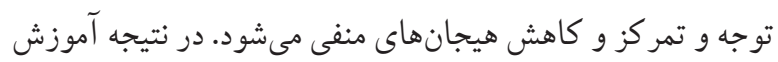

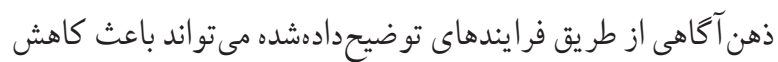
استرس و افسردگى زنان سالمند مبتلا به درد مزمن شود.

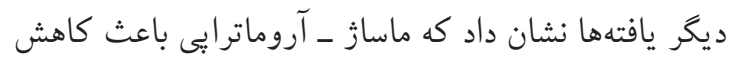
معنادار استرس ادراكشده و افسردگى زنان سالمند مبتلا به درد

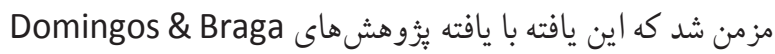

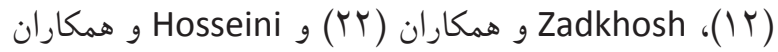

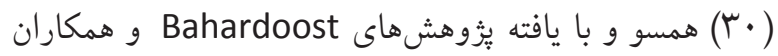


مىتوان ثُزوهش حاضر را روى مردان سالمند مبتلا به درد مزمن

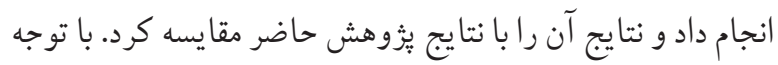

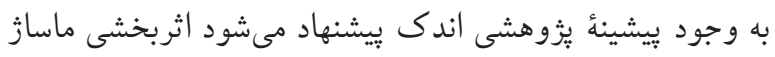

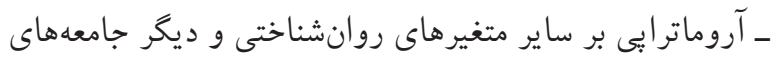

$$
\begin{aligned}
& \text { يُخوهشى ارزيابى شود. } \\
& \text { نتيجاه كيرى }
\end{aligned}
$$

نتايج مطالعه حاضر، حاكى از اثربخشى آموزش ذهن آكاهى

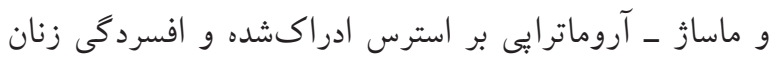

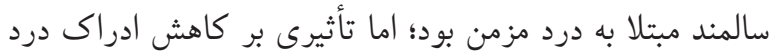

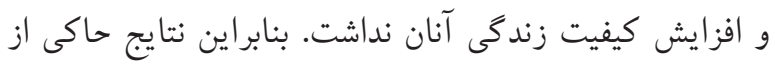

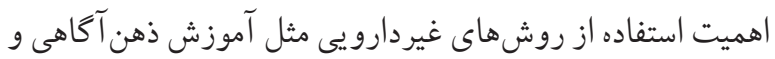

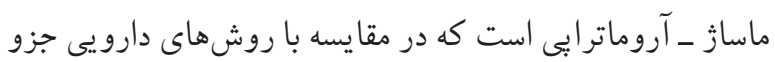
روشهاى ارزانتر، غيرتهاجمى و فاقد عوارض دارويى هستند.

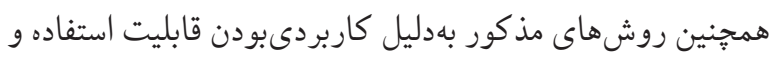

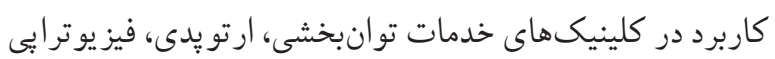
و روانشناختى را دارند. در نتيجه افر اد مداخله كننده در حيطههاى

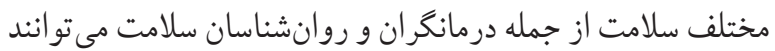
براى بهبود برخى ويز كىهاى مرتبط با سلامت روانشناختى از جمله كاهش استرس و افسردگى از روشهاى ذهن آكاهى و ماساز -

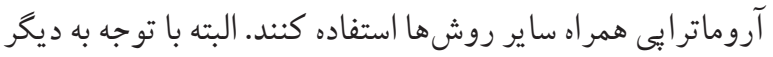
نتايج ييشنهاد مى شود كه براى بهبود برخى ديخر از ويز گمى ها از جمله كاهش ادراك درد و افزايش كيفيت زندگى مدت مداخله يا تعداد

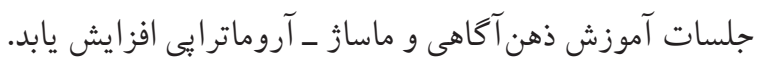
سباسگز ارى اين مقاله بر كرفته از رسالؤ دكترى روانشناسى دانشعاه آزاد اسلامى واحد كرج است كه در آن هيج تضاد منافعى وجود ندارد.

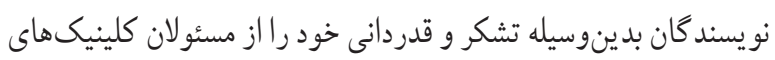
همكارى كننده و شر كت كنند گان در يُزوهش اعلام مى مدارند.

$$
\text { تعارض در منافع }
$$
تعارض منافع وجود ندارد.
باشند. در نتيجه ماساز ـ آروماترابى از طريق تركيب دستكارى

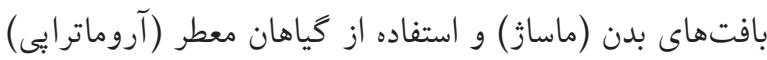
باعث كاهش مشكلات روانشناختى و ارتقاى سلامت زنان سالمند مبتلا به درد مزمن مىشود.

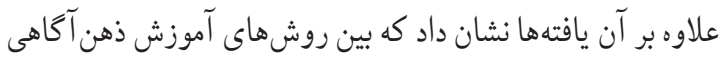

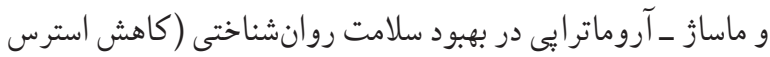

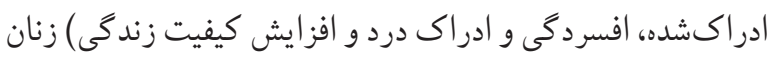

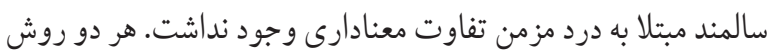
بهاطور معنادارى باعث كاهش استرس ادراكشده و افسردگى شدند

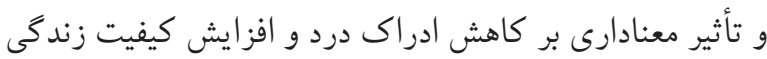
نداشتند. دليل نبود تفاوت معنادار بين دو روش مذكور كاربردى مدي مدرد

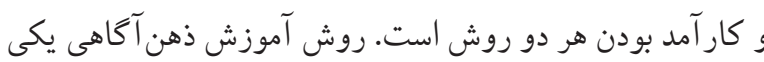

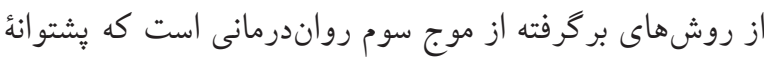

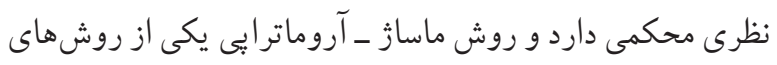

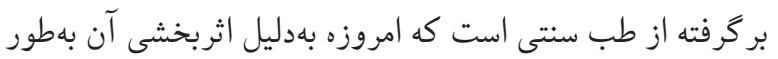

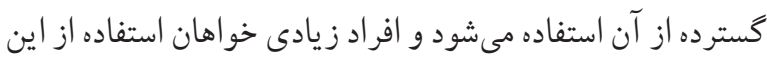

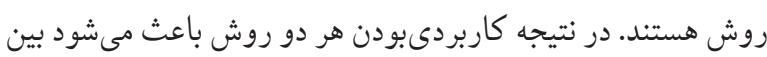

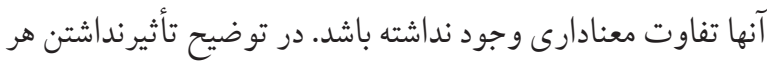

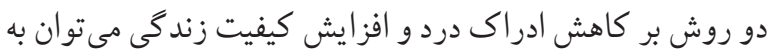
مشكلات زياد افر اد سالمند مبتلا به درد مزمن اشاره كرد و احتمالا

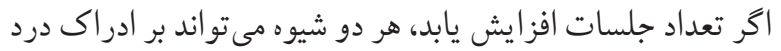
و كيفيت زندگى تأثير بحذارد.

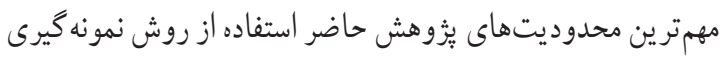
دردسترس، بررسىنكردن پِايدارى نتايج جند ماه يس از مداخله،

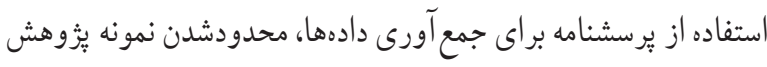

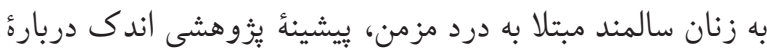
اثربخشى ماساز ـ آروماترابى و فقدان بثزوهش دربارهٔ سالمندان مبتلا

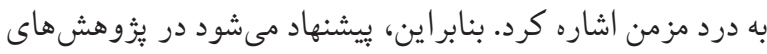

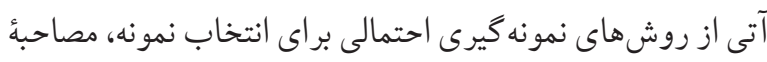

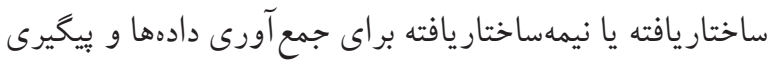

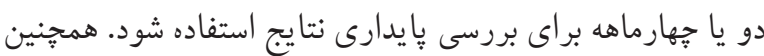




\section{References}

1. Sobhani A, Shahnazi H, Mostafavi F. The efficiency of theory-based education on mental health subscales in elders: application of theory of planned behavior. Iran J Health Educ Health Promot. 2018;6(4):367-375. https://doi.org/10.30699/acadpub.ijhehp.6.4.367

2. Maltoni B, Forti P, Zoli M, Maltoni M, Ricci M. Prevalence of Chronic Cancer and No-Cancer Pain in Elderly Hospitalized Patients: Elements for the Early Assessment of Palliative Care Needs. Int J Gerontol. 2018;12(3):180-185. https://doi.org/10.1016/j.ijge.2017.11.005

3. Arneric SP, Laird JMA, Chappell AS, Kennedy JD. Tailoring chronic pain treatments for the elderly: are we prepared for the challenge? Drug Discov Today. 2014;19(1):8-17. https://doi.org/10.1016/j.drudis.2013.08.017 PMid:24001595

4. Blackburn JP. The diagnosis and management of chronic pain. Med. 2018;46(12):786-791. https://doi.org/10.1016/j.mpmed.2018.09.001

5. Bremner JD, Campanella C, Khan Z, Fani N, Kasher N, et al. Brain mechanisms of stress and depression in coronary artery disease. J Psychiatr Res. 2019;109:76-88. https://doi.org/10.1016/j.jpsychires.2018.11.017 PMid:30508746

6. Fawzy M, Hamed SA. Prevalence of psychological stress, depression and anxiety among medical students in Egypt. Psychiatr Res. 2017;255:186-194. https://doi.org/10.1016/j.psychres.2017.05.027 PMid:28575777

7. Yagli NV, Ulger O. The effects of yoga on the quality of life and depression in elderly breast cancer patients. Complement Ther Clin Pract. 2015;21(1):7-10. https://doi.org/10.1016/j.ctcp.2015.01.002 PMid:25697379

8. Bortolussi R, Zotti P, Conte M, Marson R, Polesel J, et al. Quality of life, pain perception, and distress correlated to ultrasound-guided peripherally inserted central venous catheters in palliative care patients in a home or hospice setting. J Pain Symptom Manage. 2015;50(1):118-123. https://doi.org/10.1016/j.jpainsymman.2015.02.027 PMid:25891668

9. Yikar SK, Nazik E. Effects of prenatal education on complaints during pregnancy and on quality of life. Patient Educ Couns. 2019;102(1):119-125. https://doi.org/10.1016/j.pec.2018.08.023 PMid:30197251

10. Daoust R, Paquet J, Piette E, Sanogo K, Bailey B, Chauny JM. Impactofageonpainperceptionfortypical painfuldiagnosesin the emergency department.J Emerg Med. 2016;50(1):14-20. https://doi.org/10.1016/j.jemermed.2015.06.074 PMid:26416133
11. Keng SL, Smoski MJ, Robins CJ. Effects of mindfulness on psychological health: a review of empirical studies. Clin Psychol Rev. 2011;31(6):1041-1056. https://doi.org/10.1016/j.cpr.2011.04.006 PMid:21802619 PMCid:PMC3679190

12.DomingosTDS, BragaEM. Meaningofaromatherapymassage in mental health. Acta Paul Enferm. 2014;27(6):579-584. https://doi.org/10.1590/1982-0194201400094

13. Tapper K, Turner A. The effect of a mindfulnessbased decentering strategy on chocolate craving. Appetite. 2018;130:157-162. https://doi.org/10.1016/j.appet.2018.08.011 https://doi.org/10.1016/j.appet.2018.05.242 PMid:30099069

14. Hofmann SG, Gomez AF. Mindfulness-based interventions for anxiety and depression. Psychiatr Clin North Am. 2017;40(4):739-749. https://doi.org/10.1016/j.psc.2017.08.008 PMid:29080597 PMCid:PMC5679245

15. Gallego J, Aguilar-Parra JM, Cangas AJ, Manas I. Effect of a mindfulness program on stress, anxiety and depression in university students. The Spanish Journal of Psychology. 2014;17(109):1-6. https://doi.org/10.1017/sjp.2014.102 PMid:26055051

16. Ayik C, Ozden D. The effects of preoperative aromatherapy massage on anxiety and sleep quality of colorectal surgery patients: A randomized controlled study. Complement Ther Med. 2018;36:93-99. https://doi.org/10.1016/j.ctim.2017.12.002 PMid:29458940

17. Bervoets DC, Luijsterburg PA, Alessie JJ, Buijs MJ, Verhagen AP. Massage therapy has short-term benefits for people with common musculoskeletal disorders compared to no treatment: a systematic review. J Physiother. 2015;61(3):106-116. https://doi.org/10.1016/j.jphys.2015.05.018 PMid:26093806

18. Gok Metin Z, Arikan Donmez A, Izgu N, Ozdemir L, Arslan IE. Aromatherapy massage for neuropathic pain and quality of life in diabetic patients. J Nurs Scholarsh. 2017;49(4):379-388. https://doi . org/10.1111/jnu.12300 PMid:28605119

19. Gok Metin Z, Ozdemir L. The effects of aromatherapy massage and reflexology on pain and fatigue in patients with rheumatoid arthritis: a randomized controlled trial. Pain Manag Nurs. 2016;17(2):140-149. https://doi.org/10.1016/j.pmn.2016.01.004 PMid:27091583 
20. Chen Y, Yang H, Liu L, Fang R. Effects of mindfulness-based stress reduction on the anxiety, depression and quality of life of patients with intrauterine adhesion: a randomized controlled trial. Int J Clin Exp Med. 2017;10(2):2296-2305.

21. Sut $N$, Kahyaoglu-Sut $H$. Effect of aromatherapy massage on pain in primary dysmenorrhea: A metaanalysis. Complement Ther Clin Pract. 2017;27:5-10. https://doi.org/10.1016/j.ctcp.2017.01.001 PMid:28438280

22. Zadkhosh SM, Ariaee E, Atri AE, Rashidlamir A, Saadatyar $A$. The effect of massage therapy on depression, anxiety and stress in adolescent wrestlers. Int J Sport Stu. 2015;5(3):321-327.

23. Pourmohseni Koluri F, Eslami F. The effectiveness of group cognitive therapy based on mindfulness on mental health and quality of life of patients with irritable bowel syndrome. Health Psychology. 2017;5(20):48-67.

24. Kharatzadeh $H$, Davazdah Emamy M H, Bakhtiary $M$, Kachuei A, Mahaki B. Effectiveness of mindfulness based stress reduction on glycemic control, stress, anxiety and depression in patients with type 2 diabetes mellitus. J Urmia Univ Med Sci. 2017;28(3):206-214.

25. Vala M, Razmandeh R, Rambol K, Nasli Esfahani E, Ghodsi Ghasemabadi R. Mindfulness-based stress reduction group training on depression, anxiety, stress, selfconfidence and hemoglobin A1c in young women with type 2 diabetes. Iranian Journal of Endocrinology and Metabolism. 2016;17(5):382-390. [Persian]

26. Haddadi Kuhsar AA, Moradi A, Ghobari Bonab B, Imani F. Comparing the effectiveness of spiritual therapy based on Iranian culture with mindfulness based on reduction stress (MBSR) in reducing depression, anxiety and stress in patients with chronic pain. Clinical Psychology Studies. 2018;8(31):1-30. [Persian]

27. Imani S, Habibi M, Pashaei S, Zahiri Sorori M, Mirzaee J, Zare M. Effectiveness of mindfulness treatment on quality of life in opium abusers: promotion of the mental and physical health. Health Psychology. 2013;2(5):63-81.

28. Bahardoost $M$, Karimi S, Hejrati A, Naserifar F, Namdar $\mathrm{P}$, Chaharmahali $\mathrm{A}$, et al. A comparison between polyethylene glycol and abdominal massage on symptoms and quality of life Improvement in functional constipation: a randomize clinical trial study. J Isfahan Med Sch. 2018;36(480):557-563.

29. Anbari S, Estaji Z, Rastaqhi S. Assessment effect of Rosa damascena juice aromatherapy on elderly chronic musculoskeletal pain in Sabzevar retirement clubs. SIJA. 2018;13(2):250-261. https://doi.org/10.32598/sija.13.2.250

30. Hosseini SA, Ghasemi GA, Mardanshah M. Massage therapy effects on depression and quality of life at six weeks of depressed women. J Res Rehabil Sci. 2015;11(2):115-121.
31. Arefinia M, Ghasemi B, Arefinia S, Moradi MR. The effect of three methods of aromatherapy, massage and aromatherapy-massage on muscular pain rate of female athletes in Isfahan. 2013;5(1):55-68.

32. Mohammadi F, Mohammadkhani P, Dolatshahi B, Asghari MA. The effects of "mindfulness meditation for pain management" on the severity of perceived pain and disability in patients with chronic pain. SIJA. 2011;6(1):5966.

33. Abbasi M, Ayadi N, Pirani Z, Montazeri Z. The effect of cognitive rehabilitation on social well-being, quality of life and marital satisfaction of nurses. Iran J Health Educ Health Promot. 2017;5(3):231-239. https://doi.org/10.30699/acadpub.ijhehp.5.3.231

34. Narimani M, Ariyanpouran S, Abolghasemi A, Ahadi B. Effectiveness of mindfulness training and emotion regulation on physical and psychological well-being of chemical veterans. J Kermanshah Univ Med Sci. 2011;15(5):347-357.

35. Cohen, S, Kamarck, T, \& Mermelstein, R. A global measure of perceived stress. Journal of health and social behavior, 1983; 385-396. h tt p s: / / d o i.org / $10.2307 / 2136404$ PMid:6668417

36. Mousavi M, DashtBozorgi Z. Effect of acceptance and commitment group therapy (ACT) on the hardness and perceived stress coefficient among patients with type 2 diabetes. Iran J Health Educ Health Promot. 2017;5(4):311-319. https://doi.org/10.30699/acadpub.ijhehp.5.4.311

37. Yesavage, J. A., Brink, T. L., Rose, T. L., Lum, O., Huang, V., Adey, M., \& Leirer, V. O. Development and validation of a geriatric depression screening scale: a preliminary report. Journal of psychiatric research, 1983; 17(1): 37-49. https://doi.org/10.1016/0022-3956(82)90033-4

38. Malakouti K, Fathollahi P, Mirabzadeh A, Salavati M, Kahani S. Validation of geriatric depression scale (GDS-15) in Iran. Research in Medicine. 2006;30(4):361-369.

39. Dworkin RH, Turk DC, Revicki DA, Harding G, Coyne KS, et al. Development and initial validation of an expanded and revised version of the short-form McGill pain questionnaire (SF-MPQ-2). Pain. 2009;144(1-2):35-42. https://doi.org/10.1016/j.pain.2009.02.007 PMid:19356853

40. Khosravi M, Sadighi S, Moradi Sh, Zendehdel K. PersianMcGill pain questionnaire translation, adaptation and reliability in cancer patients: a brief report. Tehran Univ Med J. 2013;71(1):53-58. 